\title{
Dual Solutions of Forced Convection Flow along a Stretching Sheet with Variable Thickness in Presence of Free Stream and Magnetic Field
}

(Dual Penyelesaian Aliran Perolakan Dipaksa di Sepanjang Lembaran Regangan dengan Ketebalan Pemboleh Ubah dalam Kehadiran Aliran Bebas dan Medan Magnet)

\author{
UPENDRA MISHRA* \& GURMINDER SINGH
}

\begin{abstract}
The paper aims at studying forced convection in a viscous incompressible electrically conducting fluid along stretching sheet with variable thickness in the presence of variable free stream and magnetic field. The governing equations of flow and heat transfer are subjected to similarity transformation using boundary layer assumption and are then solved numerically. The system of equations possesses dual solutions for negative value of velocity power index ( $m$ ). The impact of velocity parameter $(\lambda)$ and other parameters on velocity and temperature distributions, skin friction and heat transfer are studied when system possesses dual solutions and is presented through graphs and discussed suitably. It is found that the first solution is in tune with natural physical phenomena. The second solution possesses very large skin-friction and fluid velocity as compared to the first solution. The second solution is stable and is a mere outcome of non-linearity and does not follow natural phenomena.
\end{abstract}

Keywords: Free stream; magnetic field; similarity solution; stretching surface; variable thickness

ABSTRAK

Kertas ini bertujuan mengkaji perolakan dipaksa dalam pengaliran bendalir likat tak termampat elektrik di sepanjang lembaran regangan dengan ketebalan pemboleh ubah dengan kehadiran pemboleh ubah aliran bebas dan medan magnet. Persamaan pemindahan haba dan aliran tertakluk kepada transformasi persamaan menggunakan andaian lapisan sempadan dan kemudian diselesaikan secara berangka. Sistem persamaan mempunyai dua penyelesaian untuk nilai negatif indeks tenaga halaju $(m)$. Kesan parameter halaju $(\lambda)$ dan lain-lain parameter ke atas halaju dan taburan suhu, geseran kulit dan pemindahan haba dikaji apabila sistem memiliki dual penyelesaian dan ditunjukkan melalui graf dan dibincangkan penyesuaiannya. Didapati bahawa penyelesaian yang pertama adalah sealiran dengan fenomena fizikal semula jadi. Penyelesaian yang kedua memiliki geseran kulit yang sangat besar dan halaju bendalir berbanding dengan penyelesaian yang pertama. Penyelesaian kedua adalah stabil dan hasil daripada kelinearan dan tidak mengikut fenomena semula jadi.

Kata kunci: Aliran bebas; medan magnet; penyelesaian persamaan; permukaan regangan; ketebalan pemboleh ubah

\section{INTRODUCTION}

The flow of a viscous incompressible fluid along a stretching sheet has many important applications in the extrusion process involved in plastic and metal industries. Surfaces with variable thickness help in reducing weight and are used in different civil, mechanical and marine structure related applications (Shufrin 2005). Thus, flow along surface of variable thickness adds an interesting aspect to viscous boundary layer flows. Sakiadis (1961a, 1961b) presented a seminal study dealing the flow along continuously stretching sheet. Later, many researchers addressed and contributed to different aspects of study of flow along stretching/shrinking sheets. Here we mention only those relevant to the present study, for brevity. Mahapatra and Gupta $(2002,2001)$ studied the stagnationpoint flow of a viscous incompressible electrically conducting fluid towards a stretching surface. The paper focused on effect of velocity parameter i.e. ratio of the velocity of stretching sheet to free stream velocity on heat and mass transfer. Pop et al. (2004) extended the study presented by Mahapatra and Gupta $(2002,2001)$ by adding the radiation effect to heat transfer. Ishak et al. (2009, 2006) observed the flow on vertical/horizontal stretching sheet of variable surface temperature in the presence of free stream without or with transverse magnetic field. The velocity parameter i.e. ratio of the velocity of stretching sheet to free stream velocity effected the flow and heat transfer. Sharma and Singh (2009) presented the study on MHD stagnation point flow in the presence of free stream and considered the effects of variable thermal conductivity and heat source/sink. Bhattacharyya (2013) observed the flow over a stretching sheet in the presence of free stream considering the non-uniform heat flux and the velocity parameter being an important parameter. 
Studies related to viscous flow along thin needle are present in literature (Ahmad et al. 2008; Lee 1967; Wang 1990). Fang et al. (2012) improvised and argued that non-flatness effect of stretching sheet can be investigated and analyzed boundary layer flow over a stretching sheet with variable thickness. They presented the existence of dual solution for negative values of velocity power index. Khader and Megahed (2013) extended the problem by observing slip phenomena at the surface. Subhashini et al. (2013) presented dual solution in thermal diffusive flow over a stretching sheet with variable thickness. Anjali and Prakash (2014) studied the effect of variable magnetic field on flow over a stretching sheet of variable thickness.

Cued by above, the study of boundary layer flow along the sheet of variable thickness in the presence of free stream in untouched in literature. So, in this paper we examine the forced convection in viscous incompressible electrically conducting fluid along a stretching sheet of variable thickness in the presence of free stream and variable magnetic field. The governing non-linear partial differential equations of flow and heat transfer are subjected to similarity transformation and results into a system of non-linear ordinary differential equations. The stretching sheet and free stream leads to formulation of velocity parameter. The system possesses dual solutions for negative value of velocity power index $(m)$ and in this case the effects of different parameters on both the solutions are observed and presented through figures and table.

\section{FORMULATION OF THE PROBLEM}

Consider a two dimensional forced convection flow along a horizontal stretching sheet of variable thickness (at temperature $T_{w}(x)$ ) in viscous, incompressible and electrically conducting fluid with ambient temperature $T_{\infty}$ in the presence of free stream. The Cartesian coordinate $x$ is taken along the surface motion and $y$ is perpendicular to it, in the direction from the sheet to the fluid. The sheet is of variable thickness i.e. sheet is not flat and is described by $y=A(x+b)^{(1-m) / 2}$ where $A$ is constant and $m$ is the velocity power index. The sheet is impermeable with $v_{w}=0$. The stretching velocity of the sheet is $U_{w}(x)$ $=U_{0}(x+b)^{m}$ and the free stream velocity is of the form of $U_{\infty}(x)=U_{f}(x+b)^{m}$, where $U_{0}$ and $U_{f}$ are constants. The Physical model of the problem is shown in Figure 1.

The governing equations for forced convection flow under these assumptions following Fang et al. (2012) and Subhashini et al. (2013),

$$
\begin{aligned}
& \frac{\partial u}{\partial x}+\frac{\partial v}{\partial y}=0, \\
& u \frac{\partial u}{\partial x}+v \frac{\partial u}{\partial y}=-\frac{1}{\rho} \frac{\partial p}{\partial x}+v \frac{\partial^{2} u}{\partial y^{2}}-\frac{\sigma B^{2}(x)}{\rho} u \\
& \rho C_{p}\left(u \frac{\partial T}{\partial x}+v \frac{\partial T}{\partial y}\right)=\kappa \frac{\partial^{2} T}{\partial y^{2}}
\end{aligned}
$$

where $u$ and $v$ are velocity components along $x$ and $y$ directions, respectively, $v(=m / r)$ is the kinematic viscosity; $\mu$ is the coefficient of fluid viscosity; $\rho$ is the density of fluid; $B(x)$ is the variable magnetic field; $\sigma$ is the electrical conductivity; $p$ is the pressure; $C_{p}$ is the specific heat at constant pressure; $\kappa$ is the thermal conductivity; and $T$ is the fluid temperature within boundary layer.

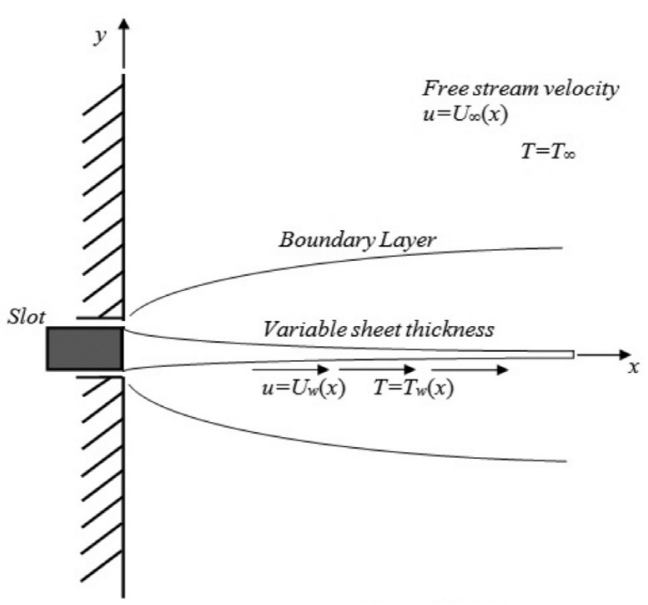

FIGURE 1. Physical Model

Due to free stream i.e. $U_{\infty}(x)=U_{f}(x+b)^{m}$ therefore

$$
U_{\infty} \frac{\partial U_{\infty}}{\partial x}=-\frac{1}{\rho} \frac{\partial p}{\partial x}-\frac{\sigma B^{2}(x)}{\rho} U_{\infty} .
$$

Eliminating $\frac{\partial p}{\partial x}$ between (2) and (4), we obtain

$$
u \frac{\partial u}{\partial x}+v \frac{\partial u}{\partial y}=U_{\infty} \frac{\partial U_{\infty}}{\partial x}+v \frac{\partial^{2} u}{\partial y^{2}}-\frac{\sigma B^{2}(x)}{\rho}\left(u-U_{\infty}\right) .
$$

The boundary conditions are:

$$
\begin{aligned}
& u\left(x, A(x+b)^{\frac{1-m}{2}}\right)=U_{0}(x+b)^{m}, v\left(x, A(x+b)^{\frac{1-m}{2}}\right)=0, \\
& T\left(x, A(x+b)^{\frac{1-m}{2}}\right)=T_{w}(x) \\
& u(x, \infty) \rightarrow U_{\infty}(x), \quad T(x, \infty) \rightarrow T_{\infty} .
\end{aligned}
$$

\section{METHOD OF SOLUTION}

Introducing the stream function $\psi(x, y)$ such that $u=\frac{\partial \psi}{\partial y}$ and $v=-\frac{\partial \psi}{\partial x}$ therefore (1) is identically satisfied. The similarity transformation for (1), (3) and (5) and boundary condition (6) are given as $\psi(x, y)=f(\xi) \sqrt{\frac{2 v U_{0}(x+b)^{m+1}}{(m+1)}}$, $\xi(x, y)=\sqrt{\frac{(m+1) U_{0}}{2 v}}\left[y(x+b)^{\frac{m-1}{2}}-A, \theta(\xi)=\frac{T-T_{\infty}}{T_{w}-T_{\infty}}\right.$ where $\xi$ 
is similarity variable; $f(\xi)$ is dimensionless stream function; and $\theta(\xi)$ is dimensionless fluid temperature. The sheet temperature is given as $T_{w}(x)=T_{\infty}+T_{0}(x+b)^{\frac{m}{2}}$ and variable magnetic field is of the form $B(x)=B_{0}(x+b)^{\frac{m-1}{2}}$. Using the similarity variables, the expression of velocities and $u$ and $v$ then take the form $u(x, \xi)=U_{0}(x+b)^{m} f^{\prime}(\xi)$ and

$$
\begin{aligned}
v(x, \xi)= & -(x+b)^{\frac{m-1}{2}}\left[\sqrt{\frac{(m+1) v U_{0}}{2}} f(\xi)+\right. \\
& \left.\frac{(m-1) U_{0} A}{2} f^{\prime}(\xi)+(m-1) \sqrt{\frac{v U_{0}}{2(m+1)}} \xi f^{\prime}(\xi)\right],
\end{aligned}
$$

and the governing equations (3) and (5) are reduced to

$$
\begin{aligned}
& f^{\prime \prime \prime}+f f^{\prime \prime}-\frac{2 m}{(m+1)} f^{\prime 2}=-\frac{2 m \lambda^{2}}{(m+1)}-2 M\left(\lambda-f^{\prime}\right) . \\
& \frac{1}{\operatorname{Pr}} \theta^{\prime \prime}+f \theta^{\prime}-\frac{m}{(m+1)} f^{\prime} \theta=0,
\end{aligned}
$$

where $\lambda\left(=\frac{U_{f}}{U_{0}}\right)$ is the velocity parameter which is the ratio of velocity of stretching sheet to free stream velocity, $M\left(=\frac{\sigma B_{0}^{2}}{\rho U_{0}(m+1)}\right)$ magnetic parameter and $\operatorname{Pr}\left(=\frac{v}{\alpha}\right)$ is the Prandtl number.

The boundary conditions (6) are transformed into:

$$
\begin{array}{ll}
\xi=0: & f^{\prime}(0)=1 ; \quad f(0)=\beta \frac{1-m}{1+m} ; \theta(0)=1 \\
\xi \rightarrow \infty: & f^{\prime}(\infty)=\lambda ; \theta(\infty)=0,
\end{array}
$$

where $\beta\left(=A \sqrt{\frac{(m+1) U_{0}}{2 v}}\right)$ is the sheet thickness parameter.

\section{SKIN-FRICTION COEFFICIENT}

The skin-friction coefficient $\left(C_{f}\right)$ at the sheet surface is given by:

$$
C_{f}=\frac{\mu\left(\frac{\partial u}{\partial y}\right)_{y=A(x+b)^{\frac{1-m}{2}}}}{\frac{1}{2} \rho U_{w}{ }^{2}(x)}=\sqrt{2(m+1)} \mathrm{Re}_{x}^{-\frac{1}{2}} f^{\prime \prime}(0)
$$

where $\operatorname{Re}_{x}=\frac{U_{w}(x)(x+b)}{v}$ is the Reynolds Number.

\section{NUSSELT NUMBER}

The rate of heat transfer in terms of Nusselt number $\left(N_{u}\right)$ at the sheet surface is given by,

$$
N_{u}=\frac{-(x+b)\left(\frac{\partial T}{\partial y}\right)_{y=A(x+b)^{\frac{1-m}{2}}}}{\left(T_{w}-T_{\infty}\right)}=-\sqrt{\frac{m+1}{2}} \operatorname{Re}_{x}^{\frac{1}{2}} \theta^{\prime}(0)
$$

\section{RESULTS AND DISCUSSION}

The system of non-linear (8) and (9) along with boundary conditions (10) are solved numerically using fourth order Runge-Kutta method along with shooting technique. In order to validate the scheme, the values of $f^{\prime \prime}(0)$ achieved by the present scheme are cross checked with the results published by Fang et al. 2012 and Subhashini et al. 2013 when $\lambda=0, M=0$ and $\beta=0.5$. The comparison is presented in Table 1, which shows excellent match. The computations are carried for $0.2 \leq m \leq 0.95$ since in this domain the system possesses dual solution. The solutions are named as first solution and second solution. From (11) and (12) it is evident that $f^{\prime \prime}(0)$ and $-\theta^{\prime}(0)$ are measures of skin-friction (wall shear stress) and the rate of heat transfer, respectively. $f^{\prime}(\xi)$ and $\theta(\xi)$ measure the fluid velocity and temperature distribution within the boundary layer.

It is seen in Figure 2(a) that for the first solution with increase in velocity parameter $(\lambda)$ the skin-friction increases while for the second solution, as seen in Figure 2(b), skin-friction decreases. Now as $\lambda$ increases, it

TABLE 1 . Comparison of $f^{\prime \prime}(0)$ with previously published results when $\beta=0.5, \lambda=0, M=0$

\begin{tabular}{ccccccc}
\hline \multirow{2}{*}{$m$} & \multicolumn{2}{c}{ Fang et al. (2012) } & \multicolumn{2}{c}{ Subhashini et al. (2013) } & \multicolumn{2}{c}{ Present result } \\
\cline { 2 - 6 } & First Solution & Second Solution & First Solution & Second Solution & First Solution & Second Solution \\
\hline-0.55 & -1.2807 & 257.6167 & -1.2812 & 256.910 & -1.28073 & 257.6146 \\
-0.6 & -1.4522 & 59.6524 & -1.4531 & 59.453 & -1.45219 & 59.65236 \\
-0.65 & -1.7095 & 31.6977 & -1.7103 & 31.704 & -1.70946 & 31.69766 \\
-0.7 & -2.0967 & 24.1604 & -2.0974 & 23.997 & -2.09665 & 24.16041 \\
-0.75 & -2.6882 & 23.3081 & -2.6891 & 23.005 & -2.68817 & 23.30808 \\
-0.8 & -3.6278 & 27.4853 & -3.6282 & 27.201 & -3.62775 & 27.48532 \\
-0.85 & -5.2477 & 40.1885 & -5.2481 & 39.225 & -5.24766 & 40.1885 \\
-0.9 & -8.5457 & 79.3287 & -8.5463 & 79.426 & -8.5457 & 79.32835 \\
-0.95 & -18.5194 & 292.5357 & -18.5209 & 291.003 & -18.5194 & 292.52 \\
\hline
\end{tabular}




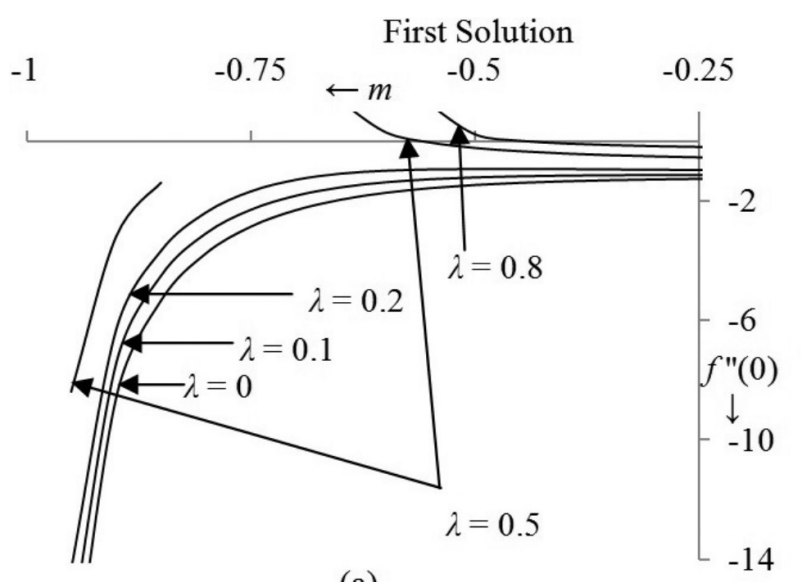

(a)
FIGURE 2. Variation of $f^{\prime \prime}(0)$ for different values of $\lambda$ versus $m$ with $\beta-0.5, M=0.25, \operatorname{Pr}=0.7$ physically means that the free stream velocity increases which in turn implies that fluid velocity in boundary layer must increase which would lead to increase in skin friction. Thus the first solution agrees with the physical phenomena. For the second solution as $m$ decreases the values of $f^{\prime \prime}(0)$ are large then dip and then again attain large value. The domain of existence of value of $f^{\prime \prime}(0)$ for first and second solution is different. In first solution the values of $f^{\prime \prime}(0)$ are majorly negative while for second solution they are positive. Looking at Figure 3(a) and 3(b) the rate of heat transfer increases with the decrease in $m$. For the second solution with the increase in $\lambda$ the rate of heat transfers increase while no clear trend is seen in the case of first solution. Figure 4(a) shows that for the first solution with the increase $\lambda$ fluid velocity increases along with increase in boundary layer thickness. Figure 4(b) depicts that with increase in $\lambda$ fluid velocity decreases. Comparing Figure $4(\mathrm{a})$ and 4 (b) for given value of $\lambda$, the fluid velocity is

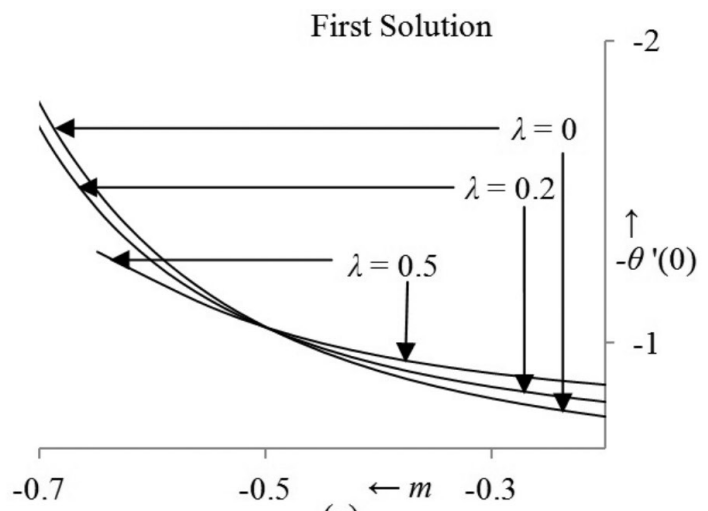

(a)

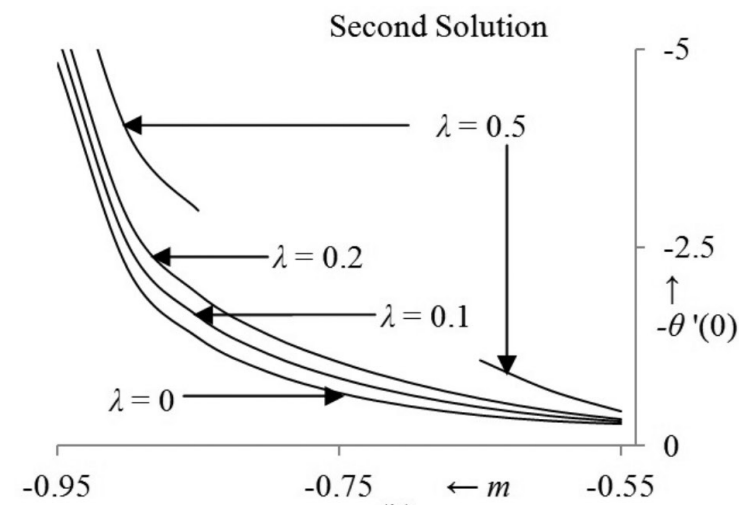

(b)

FIGURE 3. Variation of $\theta^{\prime}(0)$ for different values of $\lambda$ versus $m$ with $\beta-0.5, M=0.25, \operatorname{Pr}=0.7$

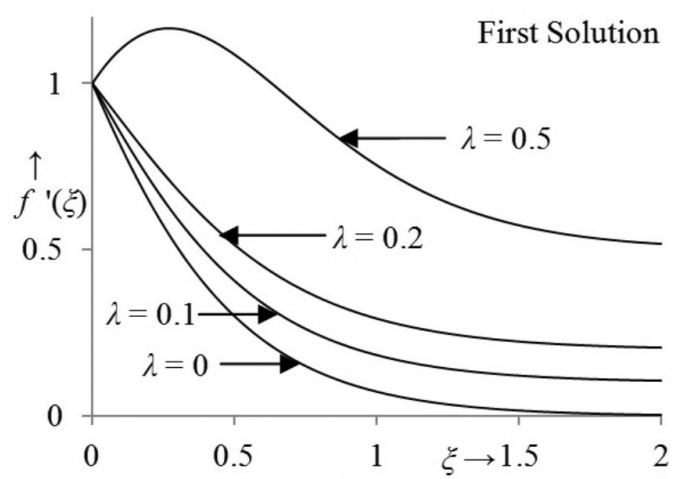

(a)

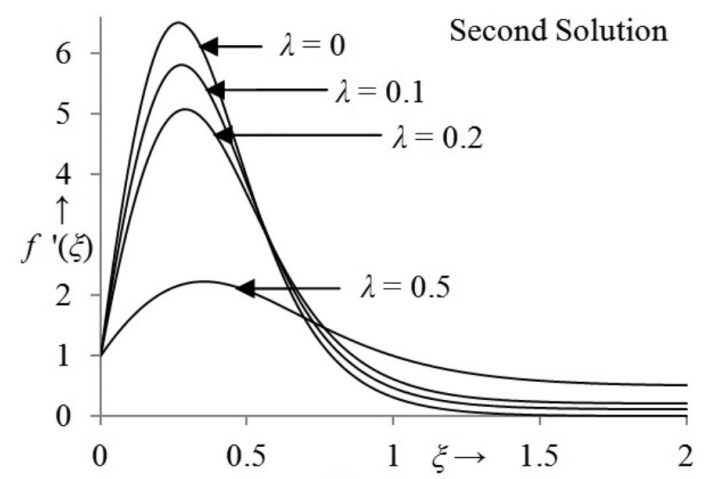

(b)

FIGURE 4. Velocity profiles (a) and (b) for different values of $\lambda$ versus $\xi$ with $m=-0.65, \beta=0.5, M=0.25, \operatorname{Pr}=0.7$ 
higher in the case of second solution. Seen in Figure 5(a) and $5(\mathrm{~b})$ the variation in fluid temperature due change in $\lambda$ is practically negligible. Thus the velocity parameter $\lambda$ majorly affects the fluid velocity. Figure $6(\mathrm{a})$ and $6(\mathrm{~b})$ shows that with the increase sheet thickness parameter $\beta$, the value of $f^{\prime \prime}(0)$ decreases for the first solution while it increases for the second solution. The increase in sheet thickness parameter means injection of fluid within the boundary layer which thickness the boundary layer and so reduces the skin-friction. The first solution agrees with this argument. It is seen that in the case of second solution the values of $f^{\prime \prime}(0)$ are very large. Further, in case of first solution the value of $f^{\prime \prime}(0)$ is negative while for second solution the value is positive. Figure 7(a) and 7(b) shows

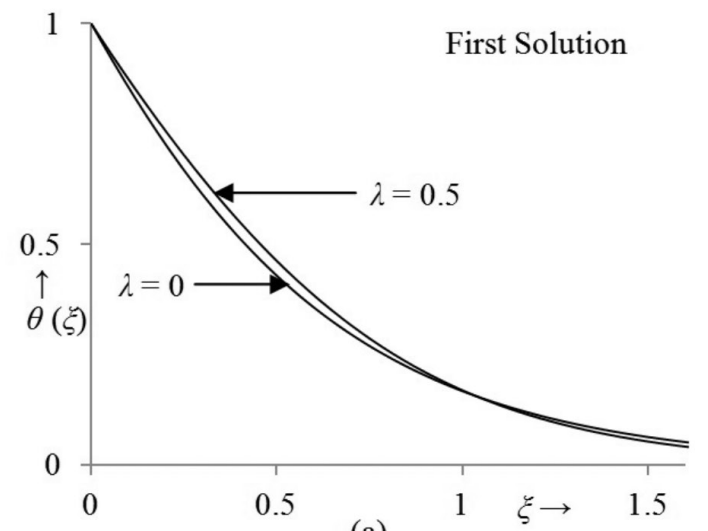

(a)

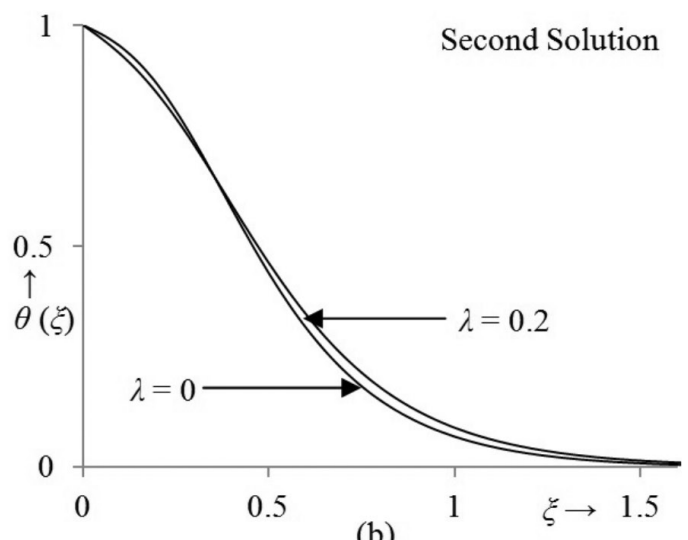

FIGURE 5. Temperature profiles (a) and (b) for different values of $\lambda$ versus $\xi$ with $m=-0.65, \beta=0.5, M=0.25, \operatorname{Pr}=0.7$

First Solution

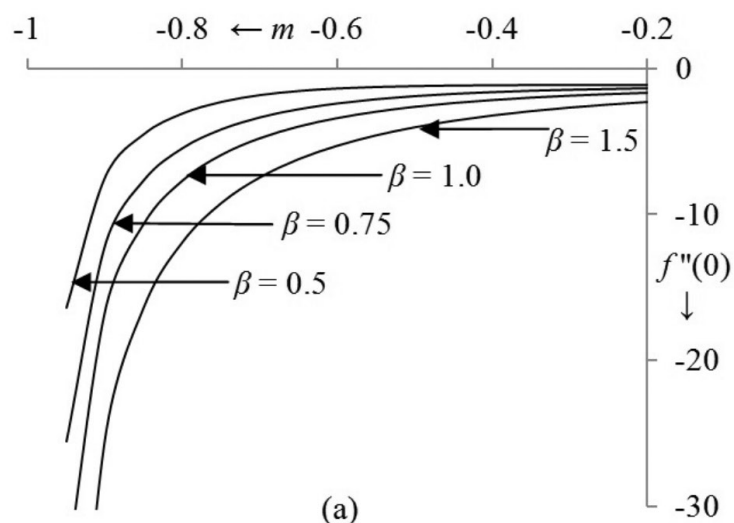

FIGURE 6. Variation of $f^{\prime \prime}(0)$ for different values of $\beta$ versus $m$ with $M=0.25, \lambda=0.1, \operatorname{Pr}=0.7$
Second Solution

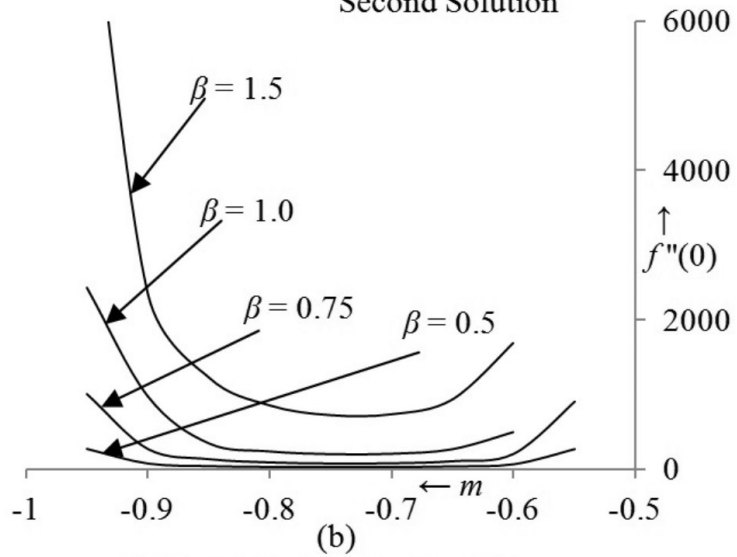

6000 4000

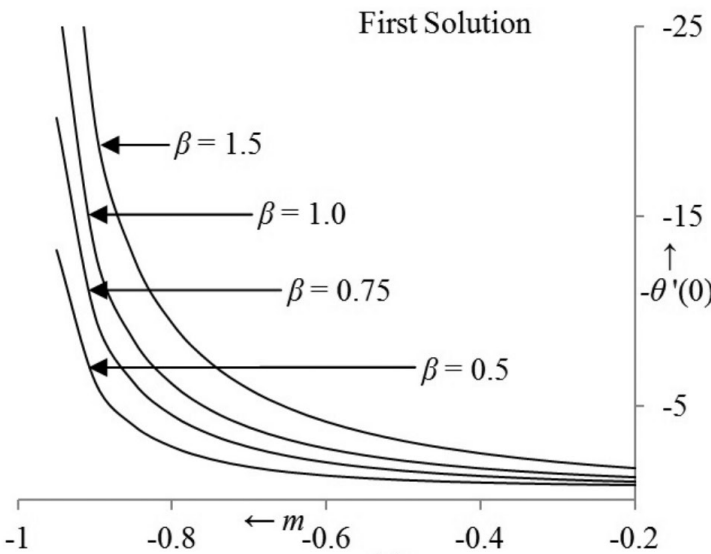

(a)

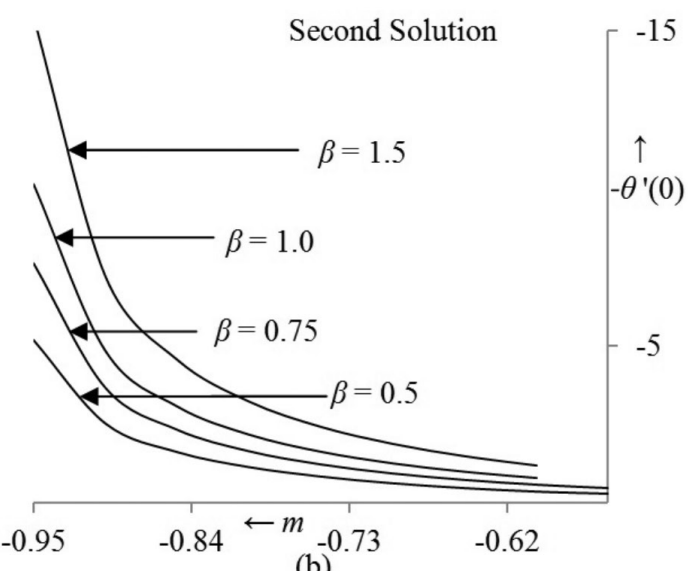

(b)

FIGURE 7. Variation of $\theta^{\prime}(0)$ for different values of $\beta$ versus $m$ with $M=0.25, \lambda=0.1, P r=0.7$ 
that with increase in $\beta$ the rate of heat transfer increases also with decrease in $m$ the rate of heat transfer increases. It is observed in Figure 8(a) that with the increase in $\beta$ the fluid velocity decreases for first solution while in Figure $8(\mathrm{~b})$ it is seen that with the increase in $\beta$ fluid velocity increases for the second solution. However, for the first solution the boundary layer is thick in comparison to second solution, for the reason explained above. A steep rise in fluid velocity is seen for second solution because of positive and large value of $f^{\prime \prime}(0)$. Figure 9(a) and 9(b) shows that with the increase in the value of $\beta$ fluid temperature decreases for both first and second solution. Figure 10(a) depicts that with the increase in Magnetic parameter $M, f^{\prime \prime}(0)$ decrease for the first solution while it is seen from Figure 10(b) that with the increase in $M, f^{\prime \prime}(0)$ increases. Also, the value of $f^{\prime \prime}(0)$ is negative for first solution and positive for second solution. As is observed from Figure 11(a) and 11(b) that with the increase in $M$ the rate of heat transfer decrease for both first and second solution. From Figure 12(a) it is seen that with the increase in $M$ fluid velocity decreases for the first solution. This is true, since the presence of magnetic field results in application of Lorentz force which in turn retards fluid velocity. However, from Figure 12(b) it is observed that with increase in $M$ fluid velocity increases. Hence first solution agrees with the natural phenomena. Figure 13(a) and 13(b) depicts that with the change in $M$ the fluid temperature distribution is negligibly effected. Figure 14(a) and 14(b) shows that with the decrease in velocity power index $m$ the fluid velocity decreases and a sharp rise in fluid velocity seen in case of second solution. It is also noted that boundary layer thickness is larger in case of first solution. Furthermore, from Figure 15(a) it is seen that with the decrease in $m$, the fluid temperature decreases but no clear trend is seen for the second solution as depicted in Figure 15(b). Figure 16(a) and 16(b) depicts with the increase in Prandtl number $\mathrm{Pr}$, the rate of heat transfer decrease and interesting to observe that for second solution at $P r=0.2$ the rate of heat transfer is almost zero. It is observed from Figures 17(a) and 17(b) that with the increase in $\operatorname{Pr}$ the fluid temperature decreases for both first and second solution. It is also seen that thermal boundary layer is thicker in case of first solution.
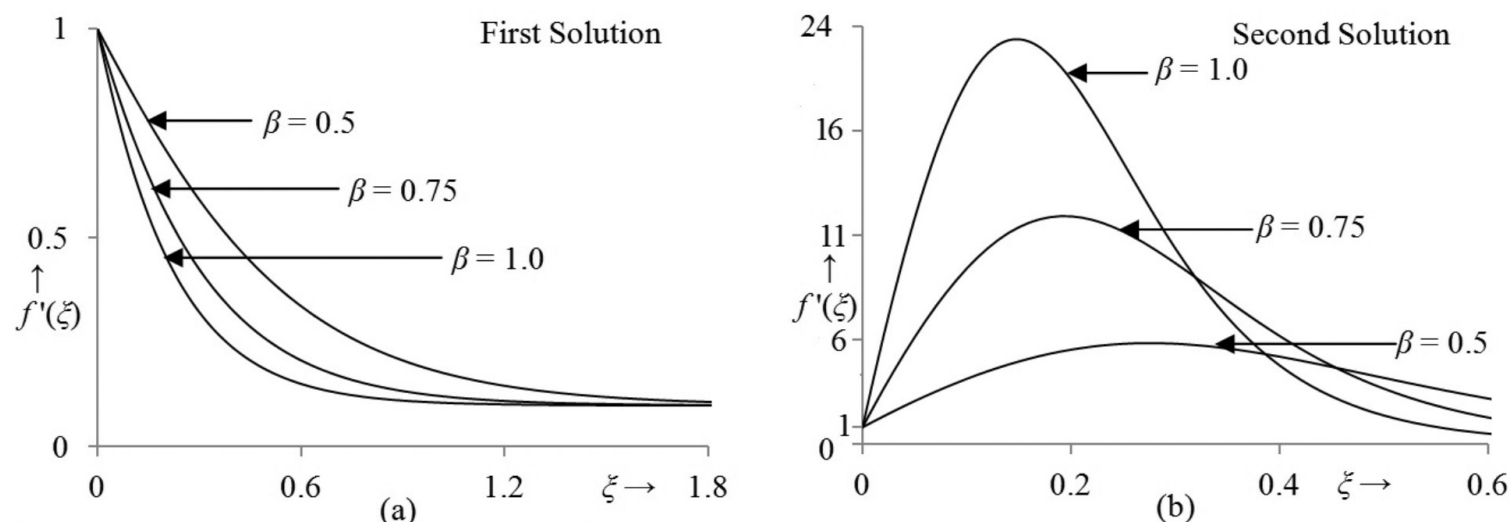

FIGURE 8. Velocity profiles (a) and (b) for different values of $\beta$ versus $\xi$ with $m=-0.65, \lambda=0.1, M=0.25, \operatorname{Pr}=0.7$
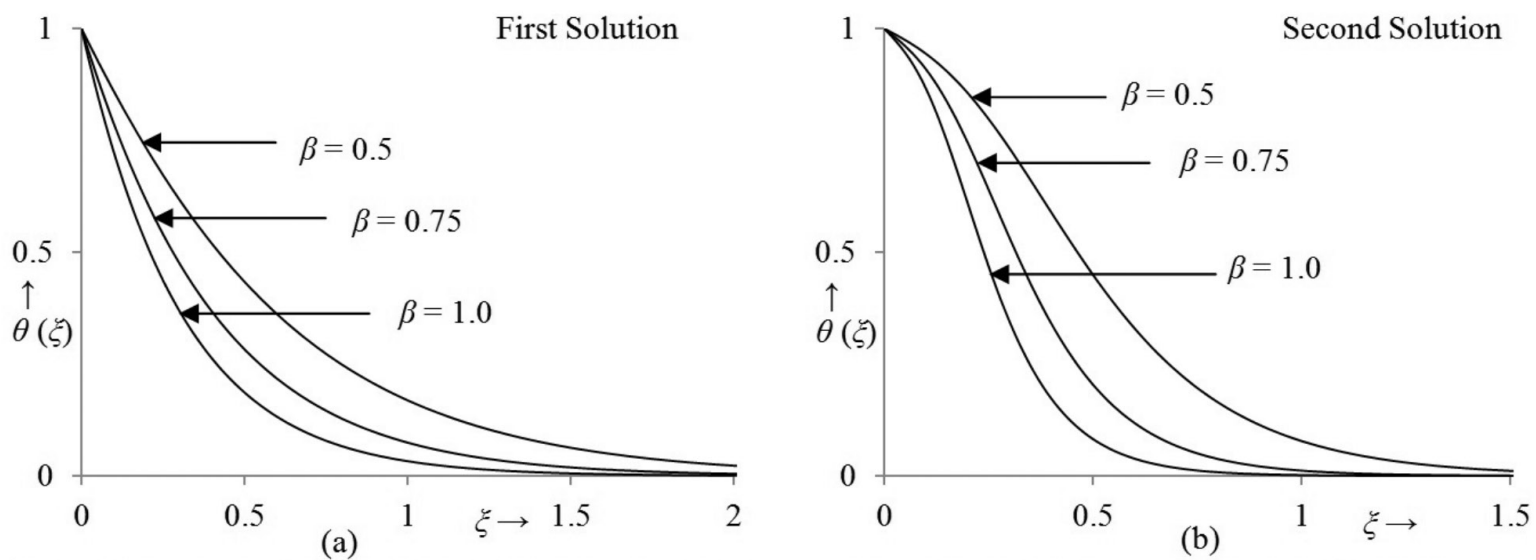

FIGURE 9. Temperature profiles (a) and (b) for different values of $\beta$ versus $\xi$ with $m=-0.65, \lambda=0.5, M=0.25, \operatorname{Pr}=0.7$ 

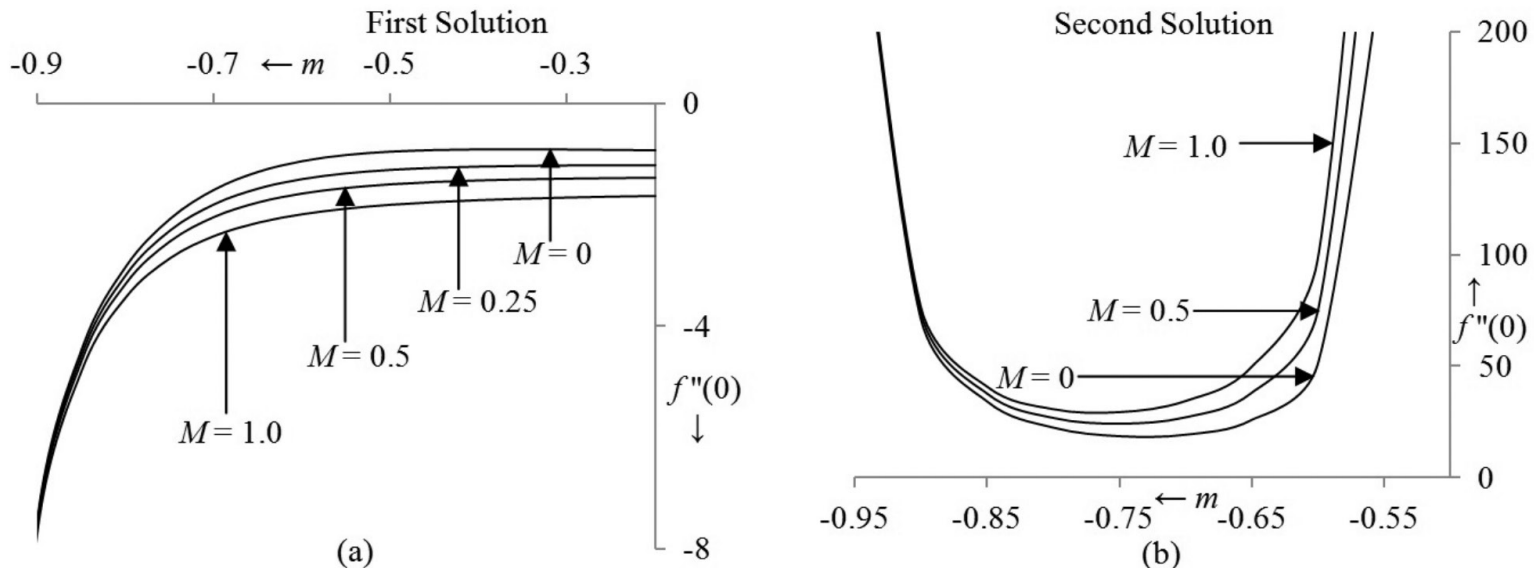

FIGURE 10. Variation of $f^{\prime \prime}(0)$ for different values of $M$ versus $m$ with $\beta=0.5, \lambda=0.1, \operatorname{Pr}=0.7$

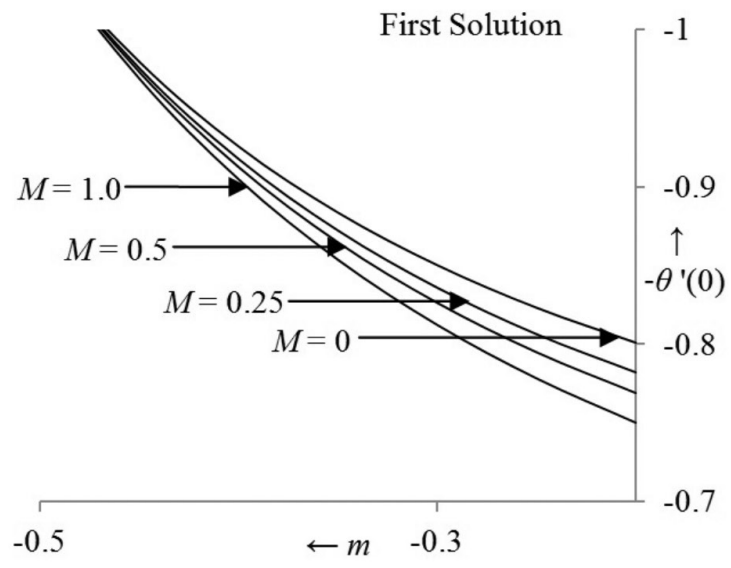

(a)

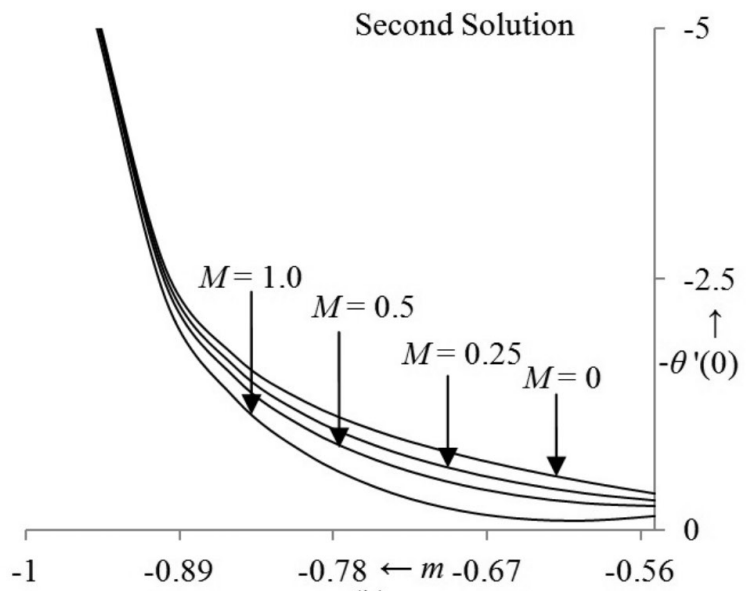

(b)

FIGURE 11. Variation of $\theta^{\prime}(0)$ for different values of $M$ versus $m$ with $\beta=0.5, \lambda=0.1, \operatorname{Pr}=0.7$
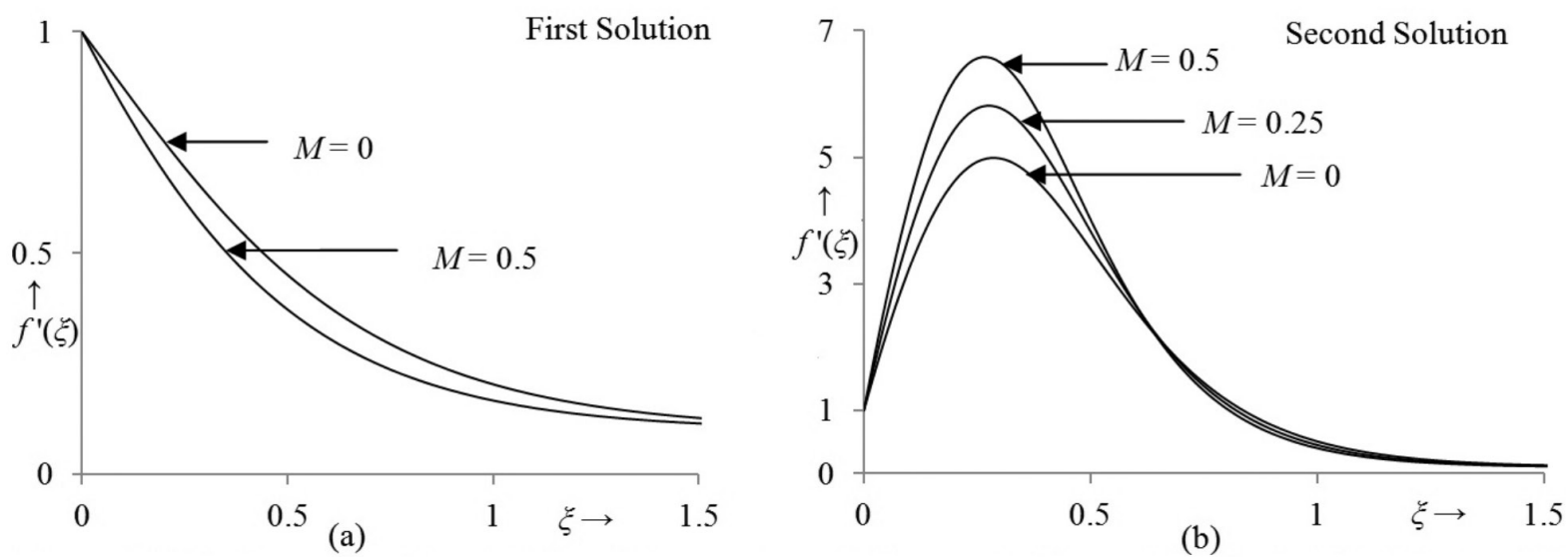

FIGURE 12 . Velocity profiles (a) and (b) for different values of $M$ versus $\xi$ with $m=-0.65, \lambda=0.1, \beta=0.5, P r=0.7$ 


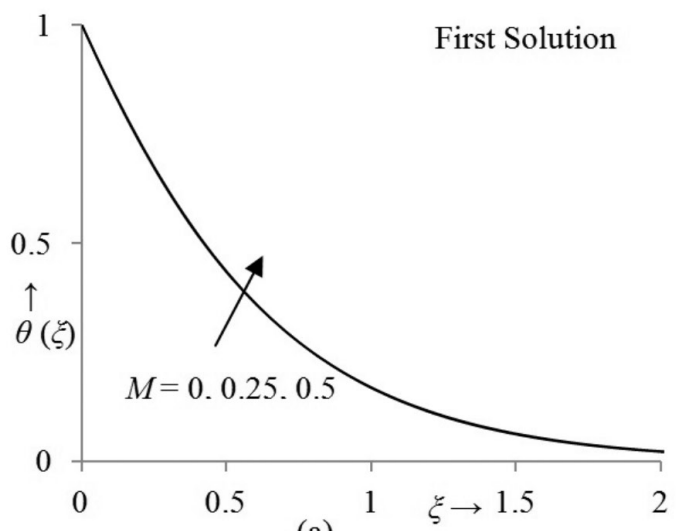

(a)

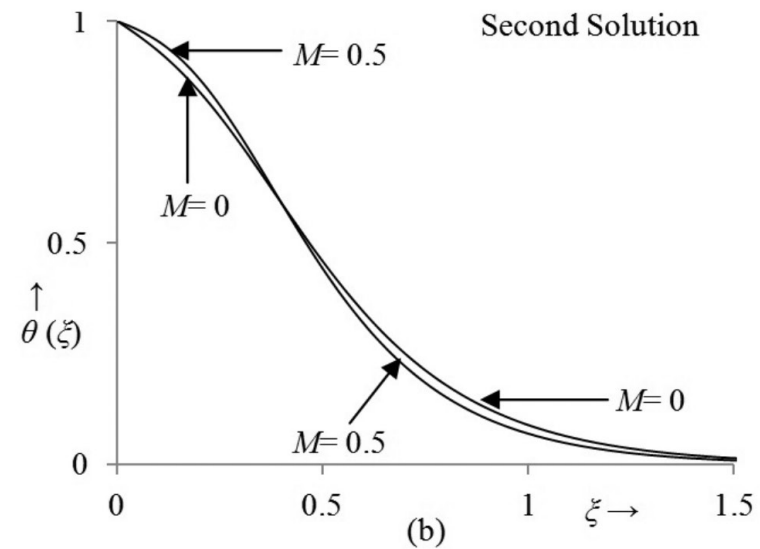

(b)

FIGURE 13. Temperature profiles (a) and (b) for different values of $M$ versus $\xi$ with $m=-0.65, \lambda=0.1, \beta=0.5, \operatorname{Pr}=0.7$
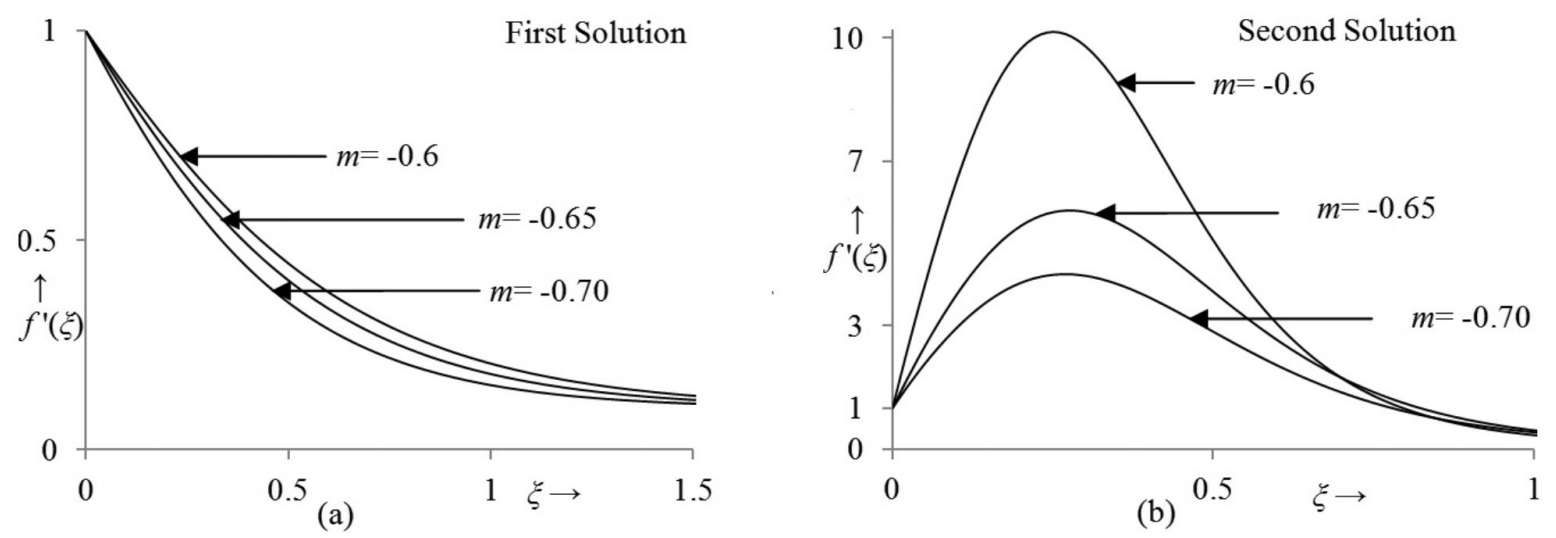

FIGURE 14. Velocity profiles (a) and (b) for different values of $m$ versus $\xi$ with $M=0.25, \lambda=0.1, \beta=0.5, \operatorname{Pr}=0.7$
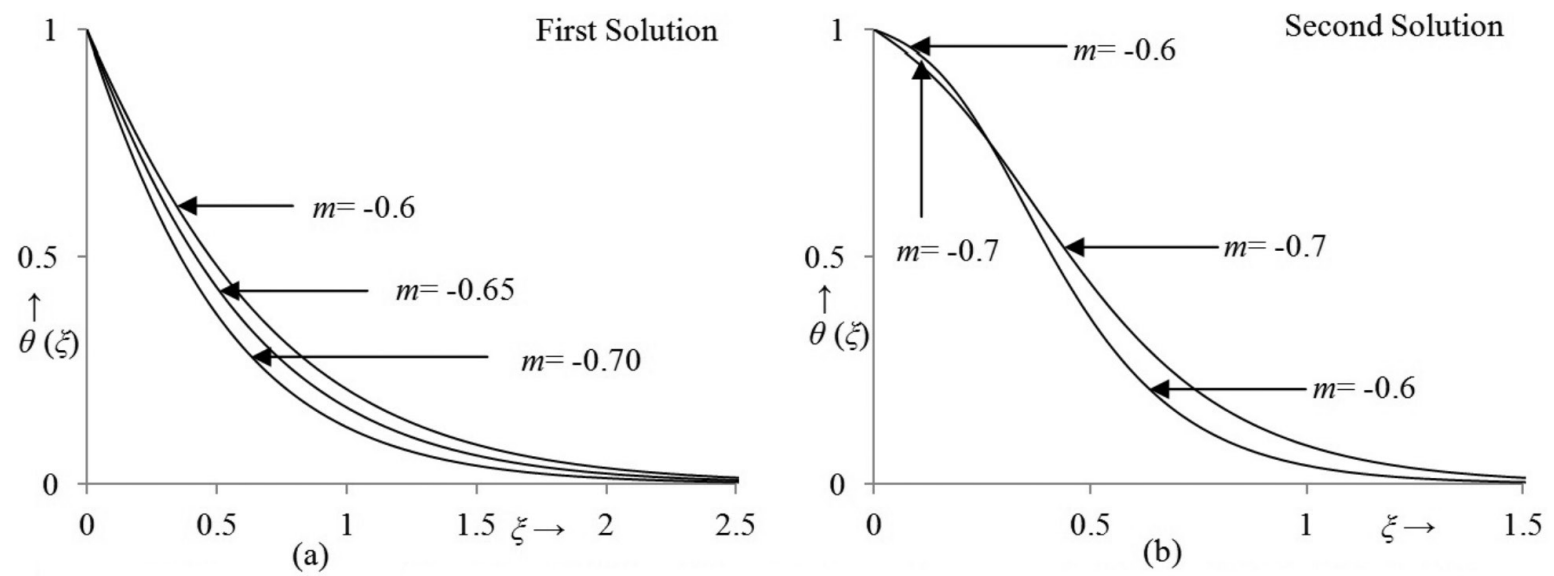

FIGURE 15. Temperature profiles (a) and (b) for different values of $m$ versus $\xi$ with $M=0.25, \lambda=0.1, \beta=0.1, \operatorname{Pr}=0.7$ 


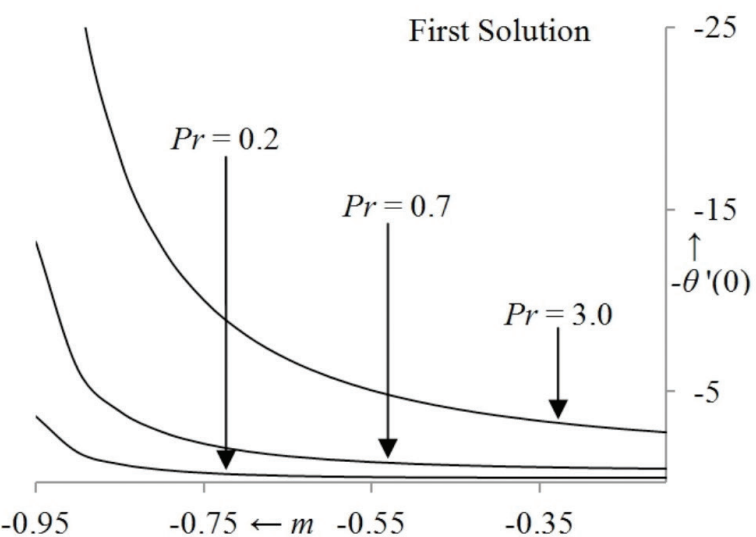

(a)

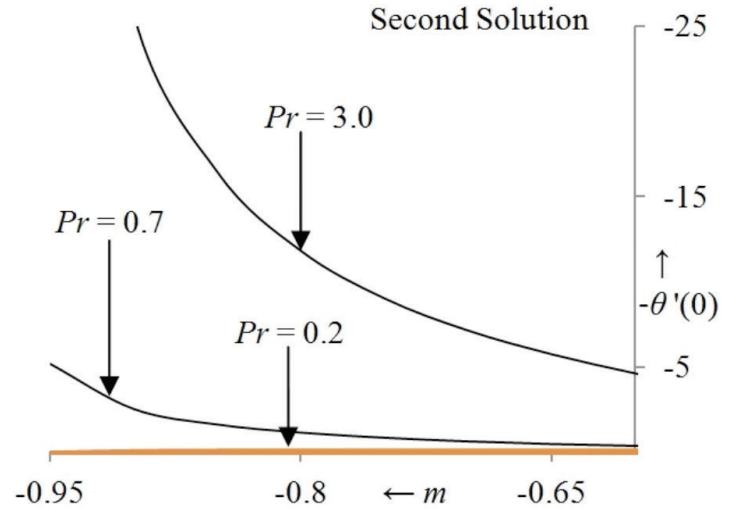

(b)

FIGURE 16. Variation of $\theta^{\prime}(0)$ for different values of $\operatorname{Pr}$ versus $m$ with $\beta=0.5, \lambda=0.1, H=0.25$

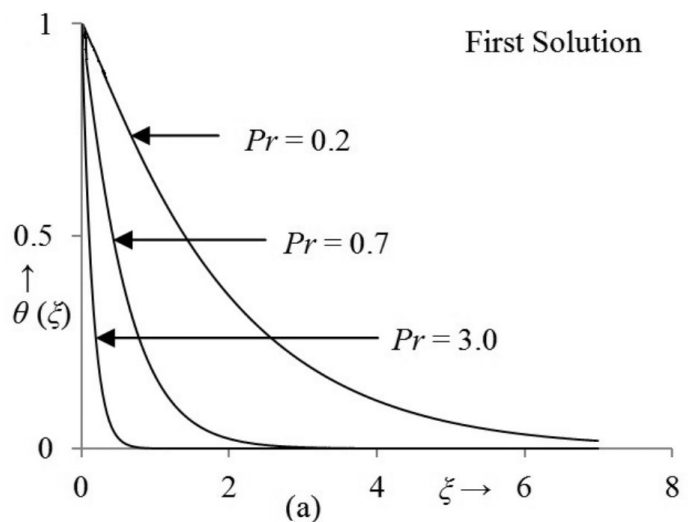

FIGURE 17. Temperature profiles (a) and (b) for different values of $\operatorname{Pr}$ versus $\xi$ with $m=-0.65, \lambda=0.1, \beta=0.5, M=0.25$

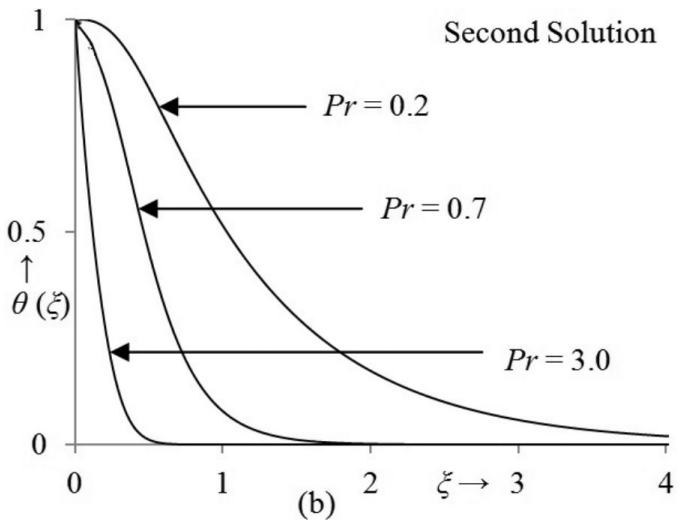

(b)

\section{CONCLUSION}

Forced convection along a sheet of variable thickness in the presence of free stream and magnetic field has been studied numerically. The system of equations governing the flow possess dual solution when the $0.2 \leq m \leq 0.95$. It is found that the first solution agrees with the physical phenomena while second solution deviates from physically reality. For the second solution the fluid velocity is very high. The second solution behaves in opposite manner to the first solution. The second solution is existent due to non-linearity and is found to be numerically stable.

\section{REFERENCES}

Ahmad, S., Arifin, N.M., Nazar, R. \& Pop, I. 2008. Mixed convection boundary layer flow along vertical thin needles: Assisting and opposing flows. Int. Commun. Heat Mass Transfer 35: 157-162.

Anjali Devi, S.P. \& Prakash, M. 2014. Steady nonlinear hydromagnetic flow over a stretching sheet with variable thickness and variable surface temperature. Journal of the Korea Society for Industrial and Applied Mathematics 18(3): 245-256.
Bhattacharyya, K. 2013. Heat transfer in boundary layer stagnation-point flow towards a shrinking sheet with non-uniform heat flux. Chinese Physics Letters B 22(7): 074705(1-6).

Fang, T., Zhang, Ji. \& Zhong, Y. 2012. Boundary layer flow over a stretching sheet with variable thickness. Applied Mathematics and Computation 218: 7241-7252.

Ishak, A., Jafar, K., Nazar, R. \& Pop, I. 2009. MHD stagnation point flow towards a stretching sheet. Physica A 388(13): 3377-3383.

Ishak, A., Nazar, R. \& Pop, I. 2006. Mixed convection boundary layers in the stagnation-point flow toward a stretching sheet. Meccanica 41: 509-518.

Khader, M.M. \& Megahed, A.M. 2013. Numerical solution for boundary layer flow due to a nonlinearly stretching sheet with variable thickness and slip velocity. The European Physical Journal Plus 128: 100.

Lee, L.L. 1967. Boundary layer over a thin needle. Phys. Fluids 10(4): 822-828.

Mahapatra, T.R. \& Gupta,A.S.2002. Heat transfer in stagnationpoint flow towards a stretching sheet. Heat and Mass Transfer 38: 517-521.

Mahapatra, T.R. \& Gupta, A.S. 2001. Magnetohydrodynamic stagnation-point flow towards a stretching sheet. Acta Mechanica 152: 191-196. 
Pop, S.R., Grosan, T. \& Pop, I. 2004. Radiation effect on the flow near the stagnation point of stretching sheet. Technische Mechanic 25: 100-106.

Sakiadis, B.C. 1961a. Boundary-layer behavior on continuous solid surface: I Boundary-layer equations for two-dimensional and axisymmetric flow. J. AIChe 7: 26-28.

Sakiadis, B.C. 1961b. Boundary-layer behavior on continuous solid surface: II Boundary-layer equations for twodimensional and axisymmetric flow. J AIChe 7: 221-225.

Shufrin, I. \& Eisenberger, M. 2005. Stability of variable thickness shear deformable plates-first order and high order analyses. Thin-Walled Struct. 43: 189-207.

Singh, G. \& Sharma, P.R. 2009. Effects of variable thermal conductivity and heat source/sink on MHD flow near a stagnation point on a linearly stretching sheet. Journal of Applied Fluid Mechanics 2(1): 13-21.

Subhashini, S.V., Sumathi, R. \& Pop, I. 2013. Dual solution in the thermal diffusive flow over a stretching sheet with variable thickness. International Communications in Heat and Mass Transfer 48: 61-66.

Wang, C.Y. 1990. Mixed convection on a vertical needle with heated tip. Phys. Fluids A 2: 622-625.
Upendra Mishra*

Department of Mathematics

Amity University Rajasthan, Jaipur

India

Gurminder Singh

Department of Applied Mathematics

Birla Institute of Technology (Ranchi)

Ext. Center Jaipur, 27

Malviya Industrial Area, Jaipur-302017

India

*Corresponding author; email: dr_umishra@yahoo.com

Received: 9 November 2015

Accepted: 18 June 2016 